\title{
Atmospheric concentrations of polycyclic aromatic hydrocarbons during chimney sweeping
}

\author{
U KNECHT,' U BOLM-AUDORFF, ${ }^{2}$ H-J WOITOWITZ1
}

From the Institute and Out-Patient Clinic for Occupational and Social Medicine of the Justus-Liebig-University of Giessen, 6300 Giessen, and Ministry of Social Welfare, ${ }^{2}$ Department of Occupational Medicine, Wiesbaden, Federal Republic of Germany

\begin{abstract}
Air sampled from the breathing zone of chimney sweeps during "dirty work" and soot samples were analysed for polycyclic aromatic hydrocarbons (PAH). A total of 20 PAH were quantified by gas chromatography-mass spectrometry in 115 air samples and 18 soot samples. These included benzo(b)fluoranthene, benzo(a)pyrene (BaP), chrysene, dibenz(a,h)anthracene, and indeno (1,2,3-cd)pyrene, all of which are animal carcinogens. The summed atmospheric concentration of these compounds depended on the type of fuel used and averaged $2.27 \mu \mathrm{g} / \mathrm{m}^{3}$ for oil fuel. If a mixture of oil and solid fuel was used the concentration was $5.06 \mu \mathrm{g} / \mathrm{m}^{3}$; pure solid fuel heating yielded 5.08 $\mu \mathrm{g} / \mathrm{m}^{3}$. The air concentrations of BaP were $0.36,0.83$, and $0.82 \mu \mathrm{g} / \mathrm{m}^{3}$ respectively. The soot samples recovered after using the three different fuel types were $10 \cdot 50,109 \cdot 10$, and $51 \cdot 25 \mathrm{mg} \mathrm{BaP} / \mathrm{kg}$. The maximum total concentrations of the five carcinogenic PAH were $243 \cdot 70,691 \cdot 06$, and $213.94 \mathrm{mg} / \mathrm{kg}$ respectively. The time weighted, shift mean concentrations of 0.02 to $0.21 \mu \mathrm{g} / \mathrm{m}^{3}$ benzo(a)pyrene obtained on 11 days form the basis for the industrial medical estimation of risk.
\end{abstract}

Epidemiological investigations have confirmed the risk of cancer to chimney sweeps as a result of the occupation specific effects of tar and soot. ${ }^{1-4}$ In particular, the results published by Gustavsson et al show that increasing duration of exposure is accompanied by an increasing frequency of lung cancer. ${ }^{5}$ No epidemiological studies are available for W Germany but several of the federal states have recently published details of casuistically malignant respiratory tract disorders in chimney sweeps. ${ }^{6}$ No adequate evidence is available concerning the cause.

Soot and tar are pyrolysis products of organic substances and contain complex mixtures of polycyclic aromatic hydrocarbons (PAH). Our aim was to investigate the PAH spectrum for carcinogenic substances in both samples of the air breathed by chimney sweeps during "black work" and in soot samples.

\section{Materials and methods}

Personal air samples were taken for chimney sweeps during black work on 11 days together with some soot samples; both were analysed for their PAH content. The air sampling lasted on average seven minutes and encompassed the actual cleaning process at the chimney. Pauses in exposure were not taken into account. Account was taken of summer and winter time when sampling. The numbers of air and soot samples subdivided into oil, oil solid fuel, and pure solid fuel are listed in the table.

To analyse for $20 \mathrm{PAH}$ the samples were subjected to four hours of Soxhlet extraction with toluene. The PAH were determined quantitatively by gas chromatography/mass spectrometry after column chromatographyic clean up and pre-enrichment. ${ }^{7}$

In what follows, of the total of 20 PAH determined, the sum of the concentrations of those five which are

Numbers of air and soot samples investigated to estimate risk of cancer to chimney sweeps from polycyclic aromatic hydrocarbons (PAH). The classification takes account of the various types of fuel used

\begin{tabular}{lllr}
\hline & \multicolumn{2}{l}{ PAH analysis } & \\
\cline { 2 - 4 } Type of firing & $\begin{array}{l}\text { No of soot } \\
\text { samples }\end{array}$ & $\begin{array}{l}\text { No of air } \\
\text { samples }\end{array}$ & $\Sigma$ \\
\hline Oil & 5 & 37 & 42 \\
Oil/solid fuel & 8 & 34 & 42 \\
Solid fuel & 5 & 44 & 49 \\
Total & 18 & 115 & 133 \\
\hline
\end{tabular}


classified in the MAK value list ${ }^{\gamma}$ as unequivocally carcinogenic in animal experiments will be set alongside that of benzo(a)pyrene (BaP). The five PAH concerned are benzo(b)fluoranthene, benzo(a)pyrene, chrysene, dibenzo(a,h)anthracene, and indeno(1,2,3,cd)pyrene.

\section{Results}

Figure 1 shows the mean concentrations in the soot samples of benzo(a)pyrene and the five PAH classified as being unequivocally carcinogenic to animals.

The soot samples from combined oil solid fuel contained higher concentrations of PAH than samples from the two other types of heating. They amounted (per kg soot) to around $41 \mathrm{mg} \mathrm{BaP}$ and $314 \mathrm{mg}$ for the sum of the five PAH. The soot samples from firing with solid fuel alone contained about half as much $\mathrm{BaP}$. With oil firing alone the BaP concentration was reduced to around $4 \mathrm{mg} / \mathrm{kg}$ - that is, by a factor of about 10. Similar trends may be seen in the summed PAH concentrations. After solid fuel alone the PAH concentration in the soot samples was, on average, $99.4 \mathrm{mg} / \mathrm{kg}$ and hence a factor of three lower than after combined oil solid fuel. On the other hand, little
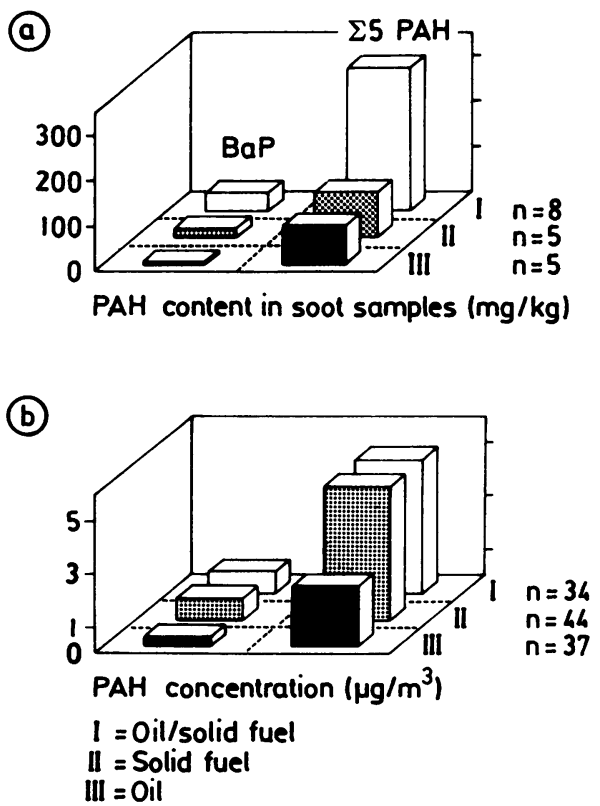

Fig 1 Means of concentrations $\left(\mu \mathrm{g} / \mathrm{m}^{3}\right)$ of benzo (a)pyrene (BaP) and sum of five polycyclic aromatic hydrocarbons $(P A H)$ in MAK list which have been unequivocally proved in animal experiments to be carcinogenic in 18 samples $(\mathrm{mg} / \mathrm{kg})$ and in 115 air samples of air breathed by chimney sweeps during their black work. Results are subdivided according to type of fuel used.
Knecht, Bolm-Audorff, Woitowit

difference was found in the soot from oil firing with combined PAH content of $83.4 \mathrm{mg} / \mathrm{kg}$.

It may also be seen from fig 1 that such differences? do not occur in the atmospheric PAH concentrations $\overrightarrow{\vec{F}}$ The BaP concentrations found for oil solid fuel firing were at $0.83 \mu \mathrm{g} / \mathrm{m}^{3}$, almost identical to those found fo pure solid fuel firing at $0.82 \mu \mathrm{g} / \mathrm{m}^{3}$. The same applied to the five chosen PAH with concentrations of 5.06 anc $5.08 \mu \mathrm{g} / \mathrm{m}^{3}$ respectively. When pure oil firing is usee the BaP concentrations at $0.36 \mu \mathrm{g} / \mathrm{m}^{3}$ and the MAK PAH concentrations at $2.27 \mu \mathrm{g} / \mathrm{m}^{3}$ were factors of 2.35 and 2.2 lower. A broad scattering was characteristic of these determinations. In particular, the standard de viations for the average atmospheric concentrations all lay over $100 \%$.

Figure 2 shows the cumulative frequencies of the $\mathrm{PAH}$ air concentrations for the various types of fuel ${ }^{\circ}$ Note should be taken of the maximum BaP concentration of $1.92 \mu \mathrm{g} / \mathrm{m}^{3}$ for oil firing and of $3.71 \mu \mathrm{g} / \mathrm{m}^{3}$ or $8.42 \mu \mathrm{g} / \mathrm{m}^{3}$ for oil solid fuel or pure solid fuel firingo respectively. Of the total of $115 \mathrm{BaP}$ determinations,, 18 , corresponding to $20.7 \%$, were over $1 \mu \mathrm{g} \mathrm{BaP} / \mathrm{m}^{3}$. Ac
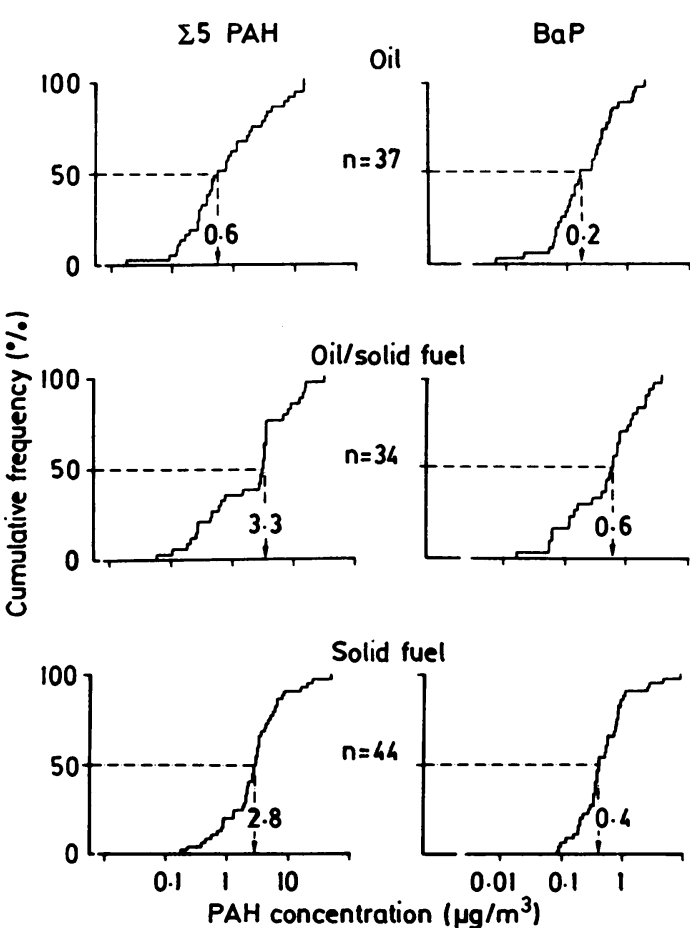

Fig 2 Cumulative frequencies (\%) of concentrations $\left(\mu \mathrm{g} / \mathrm{m}^{3}\right)$ of benzo (a) pyrene (BaP) and sum of five $\mathrm{PAH}$ in $M A K$ list which have been unequivocally proved in animal experiments to be carcinogenic in 115 samples of air breathed by chimney sweeps during their black work subdivided according to the type of fuel used. 


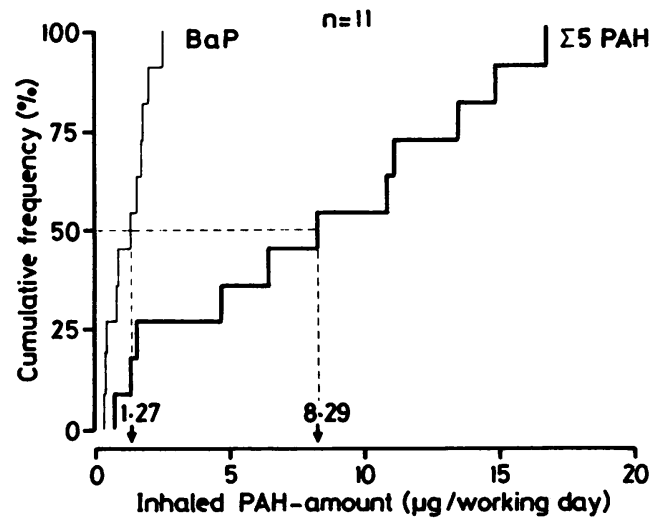

Fig 3 Calculated cumulative frequencies (\%) of benzo(a)pyrene (BaP) and sum of five PAH in MAK list which have been unequivocally proved in animal experiments to be carcinogenic on 11 working days on basis of time weighted shift means and taking volume of air respired by chimney sweeps to be $20 \cdot 8 \mathrm{l} / \mathrm{min}=10 \mathrm{~m}^{3} /$ day.

total of eight samples, corresponding to $9 \cdot 2 \%$, yielded concentrations over $2 \mu \mathrm{g} \mathrm{BaP} / \mathrm{m}^{3}$.

The frequency distribution of the summed concentrations (fig 3) shows the amounts of PAH inhaled by the chimney sweeps on the 11 days of sampling. The calculations are based on the time weighted shift means for an average of 30 cleaning operations at chimneys. It was assumed that the inhaled air volume was $10 \mathrm{~m}^{3}$ a working day. The amounts of BaP varied from 0.24 to $2.27 \mu \mathrm{g} /$ day. The median was $1.27 \mu \mathrm{g} /$ day. The extreme values for the five chosen PAH ranged from 0.68 to $16.71 \mu \mathrm{g} /$ day with a median of $8.29 \mu \mathrm{g} /$ day. In both cases the medians correspond approximately to the means of the daily PAH intakes of 1.29 and $8 \cdot 19 \mu \mathrm{g} /$ day respectively.

\section{Discussion and conclusions}

It has been possible to detect a complex spectrum of PAH in the air breathed by chimney sweeps during their periods of black work, and in soot samples. Our results agree with those reported in recent publications primarily concerned with the $\mathrm{BaP}$ concentrations in soot. ${ }^{910}$

Broad variations in concentration were determined, paricularly in the cases of the air samples. It is only possible to make a limited differentiation on the basis of the type of fuel used. The PAH concentrations emitted after oil firing show a tendency to be lower than those for the two other types of fuel.

A total of eight of the 115 atmospheric concentrations briefly exceeded the level of $2 \mu \mathrm{g} \mathrm{BaP} / \mathrm{m}^{3}$. The time weighted shift means lay maximally at about one tenth of this level. On average, about $0.09 \mu \mathrm{g} \mathrm{BaP} / \mathrm{m}^{3}$ was detected.

It is possible to calculate the daily dose of $\mathrm{BaP}$ inhaled to make an industrial medical oncological estimate of the risk to chimney sweeps during their black work. There are great differences between our results and those of Holzhauser and Schaller. " These authors gave a mean daily $\mathrm{BaP}$ intake of $100 \mu \mathrm{g}$ whereas our results are a factor of 60 -fold less at $1.3 \mu \mathrm{g}$ $\mathrm{BaP}$-assuming the same respiration volume per minute. If the extrapolation model of Pott for risk estimation, based on coke plant emissions, is applied chimney sweeps would be subject to a lung cancer frequency of $0.06 \%$ for a yearly exposure of 110 days and a 25 year working career. ${ }^{12}$ On this basis "chimney sweeping" would not be classifiable with other occupations with exposure to much higher risks from PAH, such as are to be found in coke plants, the use of carbobitumen in road building, and in manufacturing artifical coal resp electrographite. On the other hand, the $\mathrm{BaP}$ concentration alone is not sufficient to explain the epidemiologically proved risk of lung cancer to chimney sweeps. Along with the other four carcinogenic PAH discussed it is also of primary importance to explore the possibility of synergy among the causes. How far the PAH depot effect, active carbon effect, and unspecific particle mass effect, discussed by Pott in connection with the carcinogenic effects of diesel motor exhausts, ${ }^{12}$ apply to the black work of chimney sweeps must be the subject of further investigation. ${ }^{13}$

Supported by the Bundesministerium für Forschung und Technologie of the Federal Republic of Germany, Project-No 01 VD 093.

\section{References}

1 Hogstedt C, Andersson K, Frenning B, Gustavsson A. A cohort study on mortality among long time employed Swedish chimney sweeps. Scand J Work Environ Health 1982;8:72-8.

2 Hansen ES, Olsen JH, Tilt B. Cancer and noncancer mortality of chimney sweeps in Copenhagen. Int $J$ Epidemiol 1982;11:356-61.

3 Hansen ES. Mortality from cancer and ischemic heart disease in Danish chimney sweeps: a five-year follow up. Am J Epidemiol 1984;50:389-97.

4 Kupetz GW. Krebs des Atemtraktes und Schornsteinfegerberuf. Berlin: Humboldt Universität, 1966. (Inaugural dissertation.)

5 Gustavsson P, Gustavsson A, Hogstedt C. Excess mortality among Swedish chimney sweeps. $\mathrm{Br} J$ Ind $\mathrm{Med}$ 1987;44:738-43.

6 Lorenz M, Haedicke B, Grimm HG. Prävalenz bösartiger Erkrankungen des Respirations- und oberen Verdauungstraktes bei den Schornsteinfegern des Saarlandes. In: Norpoth K, ed, Verhandlungen der Deutschen Gesellschaft für Arbeitsmedizin. Stuttgart: Gentner, 
1987:403-6.

7 Knecht U, Lämmler C, Tobias S. Evaluation of various collection phases for polycyclic aromatic hydrocarbons (PAH). Fresenius Zeitschrift für Analytische Chemie 1987;326:25-32.

8 Commission for the investigation of health hazards of chemical compounds in the work area. DFG German Science Foundation. Maximum concentrations at the workplace and biological tolerance values for working materials. Weinheim: Verlag Chemie, 1987. (Report No XXIII.)

9 Medalia AJ, Rivin D, Sanders DR. A comparison of carbon black with soot. Sci Total Environ 1983;31: 1-22.

10 Rivin D, Smith RG. Environmental health aspects of carbon black. Rubber Chemical Technology

1982;55:707-61.
11 Holzhauser KP, Schaller KH. Arbeitsmedizinische Untersuchungen bei Schornsteinfegern. In: Goetz E, Wagner R. eds. Arbeit und Gesundheit. Stuttgart: G Thieme 1977;NF Heft 91.

12 Pott F. Pyrolyseabgase, PAH und LungenkrebsrisikoDaten und Bewertung. Staub-Reinhaltung der Luft $\overline{\bar{\omega}}$ 1985;45:369-79.

13 Pott F, Heinrich U. Dieselmotorabgas und Lungenkrebs-Tierexperimentelle Daten und ihre Bewertung im Hinblick auf die Gefährdung des Menschen. In: Ges z Förderung der Lufthygiene und Silikoseforschung eds. Umwelthygiene. Düsseldorf: J W Albers, 1987;Bd 19:131-67. 